\title{
Zatrudnienie skazanych w świetle danych statystycznych na przykładzie Zakładu Karnego w Inowrocławiu w latach 2011-2015
}

The convicts employment based on the statistics of Penitentiary in Inowrocław between 2011 and 2015

\section{Streszczenie:}

Celem wykonania kary pozbawienia wolności jest wzbudzenie w skazanym woli współdziałania w kształtowaniu jego społecznie pożądanych postaw. Dla osiągnięcia tego celu stosuje się szereg środków oddziaływań resocjalizacyjnych, wśród których na pierwszym miejscu wymienia się pracę, zwłaszcza taką, która sprzyja zdobywaniu odpowiednich kwalifikacji zawodowych. Zgodnie z art. 121 § 1 Kodeksu karnego wykonawczego skazanemu zapewnia się w miarę możliwości świadczenie pracy, ponieważ jako pozbawiony wolności nie może tej pracy sam znaleźć. Zatrudnienie skazanych jest korzystne zarówno dla samych skazanych, jak i dla pracodawców. Ogromne znaczenie mają także względy resocjalizacyjne. $\mathrm{W}$ artykule zaprezentowano analizę poziomu zatrudnienia skazanych w Zakładzie Karnym w Inowrocławiu w latach 2011-2015. Autorka dokonała przeglądu poszczególnych kategorii zatrudnienia skazanych, a także wskazała na zarysowujące się w tym zakresie kierunki zmian.

Słowa kluczowe: zatrudnienie, skazani, zakład karny 
Dorota Kanarek-Lizik - Zatrudnienie skazanych...

\begin{abstract}
:
The aim of the imprisonment penalty is to arouse the willingness of cooperation of the convict in order to shape the preferable social attitudes. To achieve this goal a number of rehabilitation means are applied. The priority here is an employment which helps to acquire professional qualifications. If possible, the convict is provided a workplace because as a liberty deprived person, he is unable to do it personally, in accordance to Rule $121 \S 1$ of Penal Code. Employing the convicts is profitable for both sides; the convicts and the employers. Additionally, rehabilitation reasons are also significant. This article presents the analysis of the level of the convicts employment in Penitentiary in Inowrocław between 2011-2015. The author surveyed the individual categories of the convicts employment and mentioned the new directions of changes in this area.
\end{abstract}

Keywords: employment, convicted, penitentiary

\title{
Regulacje prawne dotyczące zatrudnienia skazanych
}

Kodeks karny wykonawczy w art. 67 określa podstawowy cel wykonywania kary pozbawienia wolności, którym jest wzbudzenie w skazanym woli współdziałania w kształtowaniu jego społecznie pożądanych postaw, w szczególności poczucia odpowiedzialności oraz potrzeby przestrzegania porządku prawnego i tym samym powstrzymania się od powrotu do przestępstwa. Dla osiągnięcia tego celu prowadzi są zindywidualizowane oddziaływania na skazanych w ramach systemów wykonania kary oraz w różnych rodzajach i typach zakładów karnych. W § 3 tego artykułu wśród środków oddziaływań resocjalizacyjnych na pierwszym miejscu wymienia się pracę, zwłaszcza taką, która sprzyja zdobywaniu odpowiednich kwalifikacji zawodowych.

Osoba odbywająca karę pozbawienia wolności ma prawo do pracy tak samo jak człowiek wolny, dlatego też zgodnie z art. 121 k.k.w skazanemu zapewnia się $\mathrm{w}$ miarę możliwości świadczenie pracy. Skazanego zatrudnia się na podstawie skierowania do pracy albo 
umożliwia się skazanemu wykonywanie pracy zarobkowej w ramach umowy o dzieło, umowy o pracę nakładczą lub na innej podstawie prawnej.

Pracę zapewnia się przede wszystkim tym skazanym, którzy są zobowiązani do świadczeń alimentacyjnych oraz mają trudną sytuację materialną, osobistą lub rodzinną (art. 122 § 2 k.k.w).

Skazani wykonują pracę odpłatną, z zastrzeżeniem art. 123a k.k.w, który przewiduje możliwość nieodpłatnego zatrudnienia za prace porządkowe oraz pomocnicze wykonywane na rzecz jednostek organizacyjnych Służby Więziennej lub za prace porządkowe na rzecz samorządu terytorialnego, w wymiarze nie przekraczającym 90 godzin miesięcznie. Taka forma zatrudnienia jest możliwa za pisemną zgodą lub na wniosek skazanego.

$\mathrm{Z}$ dniem 8 marca 2011 roku w wyniku zmiany przepisu w Kodeksie karnym wykonawczym, dotyczącego wynagradzania skazanego zatrudnionego w pełnym wymiarze czasu pracy, wynagrodzenie więźnia musi być równe co najmniej wysokości obowiązującej płacy minimalnej. W myśl art. $125 \S 1$ k.k.w z przysługującego skazanemu wynagrodzenia za pracę potrąca się:

- $10 \%$ na cele Funduszu Pomocy Pokrzywdzonym oraz Funduszu Pomocy Postpenitencjarnej,

- $25 \%$ na cele Funduszu Aktywizacji Zawodowej Skazanych oraz Rozwoju Przywięziennych Zakładów Pracy.

Na podstawie art. 8. 1. ustawy z dnia 28 sierpnia 1997 r. o zatrudnieniu osób pozbawionych wolności środki Funduszu Aktywizacji Zawodowej Skazanych oraz Rozwoju Przywięziennych Zakładów Pracy przeznacza się na finansowanie działań w zakresie resocjalizacji osób pozbawionych wolności, a w szczególności na:

1) tworzenie nowych miejsc pracy dla osób pozbawionych wolności oraz ochronę istniejących,

2) tworzenie w zakładach karnych infrastruktury niezbędnej do działań resocjalizacyjnych,

3) modernizację przywięziennych zakładów pracy i ich produkcji, 
Dorota Kanarek-Lizik - Zatrudnienie skazanych...

4) organizowanie nauki zawodu i doskonalenia zawodowego dla osób pozbawionych wolności,

5) organizowanie szkolenia $w$ zakresie aktywizacji zawodowej i umiejętności poszukiwania pracy.

Z tytułu zwiększonych kosztów zatrudnienia osób pozbawionych wolności przedsiębiorcy zatrudniający te osoby otrzymują z Funduszu ryczałt w wysokości $20 \%$ wartości wynagrodzeń przysługujących pracującym skazanym. Ponadto ze środków Funduszu mogą być przyznawane pożyczki bądź dotacje przedsiębiorcom zatrudniającym osoby pozbawione wolności (art. 8. 2. ustawy o zatrudnieniu osób pozbawionych wolności).

\section{Zatrudnienie skazanych w Areszcie Śledczym w Inowrocławiu w latach 2011-2013}

Więzienie w Inowrocławiu jest jedną z jednostek penitencjarnych położonych na Kujawach Zachodnich. Podlega Okręgowemu Inspektoratowi Służby Więziennej w Bydgoszczy. Położone jest na terenie województwa kujawsko-pomorskiego.

Inowrocławska jednostka penitencjarna w swojej ponad 100-letniej historii funkcjonowała zarówno jako Zakład Karny jak i Areszt Śledczy.

Zarządzeniem Nr 23/84 CZZK Ministra Sprawiedliwości z dnia 15 maja 1984 roku istniejący Zakład Karny w Inowrocławiu stał się Aresztem Śledczym. Jako przeznaczenie wskazano, że jest to areszt śledczy, oddział dla recydywistów penitencjarnych ZK typu zamkniętego, półotwartego i otwartego. Zarządzeniem Ministra Sprawiedliwości z dnia 8 kwietnia 2014 roku Areszt Śledczy w Inowrocławiu został zniesiony. Ponownie stał się Zakładem Karnym¹.

\footnotetext{
${ }^{1}$ D. Kanarek-Lizik, W. Stankowski, Dzieje Zakładu Karnego w Inowrocławiu. Z dziejów polskich jednostek penitencjarnych, Tom II, Inowrocław 2014, s. 13.
} 
W 2011 roku w Areszcie Śledczym w Inowrocławiu przebywało 368 osadzonych (stan na dzień 31.12.2011 r.). Zatrudniano łącznie 174 osoby, co stanowiło $47,28 \%$ całej populacji (współczynnik powszechności zatrudnienia skazanych).

$\mathrm{Z}$ analizy danych zawartych w tabeli 1 . wynika, że najwięcej skazanych pracowało nieodpłatnie wykonując prace porządkowe i pomocnicze (50\%). Wśród form odpłatnego zatrudnienia skazanych najliczniejszą grupę stanowili skazani zatrudnieni przy pracach porządkowych i pomocniczych $(20,69 \%)$. Na rzecz kontrahentów zewnętrznych zatrudniano $12,64 \%$ osób pozbawionych wolności. Nieodpłatne prace publiczne i na cele charytatywne wykonywało $16,67 \%$ skazanych.

Tabela 1. Zatrudnienie skazanych w Areszcie Śledczym w Inowrocławiu w 2011 r.

\begin{tabular}{|c|c|c|}
\hline Rodzaj zatrudnienia & Liczba skazanych & Struktura [\%] \\
\hline $\begin{array}{c}\text { Odpłatne prace } \\
\text { porządkowe i pomocnicze }\end{array}$ & 36 & 20,69 \\
\hline $\begin{array}{c}\text { Nieodpłatne prace } \\
\text { porządkowe i pomocnicze }\end{array}$ & 87 & 50,00 \\
\hline $\begin{array}{c}\text { Kontrahenci } \\
\text { pozawięzienni }\end{array}$ & 22 & 12,64 \\
\hline $\begin{array}{c}\text { Prace publiczne i na cele } \\
\text { charytatywne }\end{array}$ & 29 & 16,67 \\
\hline Razem & $\mathbf{1 7 4}$ & $\mathbf{1 0 0 , 0 0}$ \\
\hline
\end{tabular}

Źródło: opracowanie własne na podstawie danych uzyskanych z OISW w Bydgoszczy.

W zatrudnieniu skazanych w 2011 roku przeważały prace nieodpłatne tj. prace porządkowe i pomocnicze oraz prace publiczne i na cele charytatywne $(66,67 \%)$. Skazani zatrudnieni w tej formie przepracowali na rzecz administracji publicznej oraz organów samorządu terytorialnego łącznie 32600 godzin.

W 2012 roku w Areszcie Śledczym w Inowrocławiu stan zaludnienia wynosił 394 osadzonych (na dzień 31.12.2012 r.). Zatrudniano 
Dorota Kanarek-Lizik - Zatrudnienie skazanych...

łącznie 172 osoby, współczynnik powszechności zatrudnienia skazanych obniżył się z 47,28\% (na koniec 2011 r.) do 43,65\% (na koniec 2012 r.).

Odnotowano zwiększenie zatrudnienia skazanych nieodpłatnie przy pracach porządkowych i pomocniczych do 59,88\% (tabela 2). Dane określające rozmiar zatrudnienia $\mathrm{w}$ formie odpłatnych prac porządkowych i pomocniczych oraz prac publicznych i na cele charytatywne pozostawały na zbliżonym poziomie w porównaniu do roku poprzedniego.

Znaczny spadek zanotowano $\mathrm{w}$ zatrudnianiu skazanych przez kontrahentów zewnętrznych, z poziomu $12,64 \%$ zarejestrowanego w 2011 roku, do 4,65\% w roku analizowanym. Spadek ten został wywołany konsekwencjami wejścia w życie, z dniem 8 marca 2011 roku zmiany przepisu w Kodeksie karnym wykonawczym, dotyczącego zasad ustalania wynagrodzenia skazanego, zatrudnianego $\mathrm{w}$ pełnym wymiarze czasu pracy oraz niechętnym podejściem do uregulowań związanych z możliwością pozyskania środków z Funduszu Aktywizacji Zawodowej Skazanych oraz Rozwoju Przywięziennych Zakładów Pracy. Poza tym zaobserwowano ograniczone zapotrzebowanie na pracę skazanych przez podmioty zewnętrzne.

Tabela 2. Zatrudnienie skazanych w Areszcie Śledczym w Inowrocławiu w 2012 r.

\begin{tabular}{|c|c|c|}
\hline Rodzaj zatrudnienia & Liczba skazanych & Struktura [\%] \\
\hline $\begin{array}{c}\text { Odpłatne prace } \\
\text { porządkowe i pomocnicze }\end{array}$ & 33 & 19,19 \\
\hline $\begin{array}{c}\text { Nieodpłatne prace } \\
\text { porządkowe i pomocnicze }\end{array}$ & 103 & 59,88 \\
\hline $\begin{array}{c}\text { Kontrahenci } \\
\text { pozawięzienni }\end{array}$ & 8 & 4,65 \\
\hline $\begin{array}{c}\text { Prace publiczne i na cele } \\
\text { charytatywne }\end{array}$ & 28 & 16,28 \\
\hline Razem & $\mathbf{1 7 2}$ & $\mathbf{1 0 0 , 0 0}$ \\
\hline
\end{tabular}

Źródło: opracowanie własne na podstawie danych uzyskanych z OISW w Bydgoszczy. 
W 2012 r. w zatrudnieniu skazanych dominowały prace nieodpłatne (76,16\%). Skazani zatrudnieni nieodpłatnie przepracowali łącznie 31400 godzin.

W 2013 roku w Areszcie Śledczym w Inowrocławiu przebywało 355 osadzonych (stan na dzień 31.12.2013 r.). Zatrudniano 161 osadzonych, współczynnik powszechności zatrudnienia skazanych podwyższył się z 43,65\% (na koniec 2012 r.) do 45,35\% (na koniec 2013 r.).

Zatrudnienie nieodpłatne skazanych $\mathrm{w}$ formie prac porządkowych i pomocniczych uległo obniżeniu w porównaniu do roku 2012 i wynosiło $49,07 \%$ (tabela 3). Więcej skazanych zatrudniano przy odpłatnych pracach porządkowych i pomocniczych $(22,98 \%)$. Wzrost zarejestrowano także w zatrudnieniu przy pracach publicznych i na cele charytatywne (21,12\%). Zatrudnienie skazanych przez kontrahentów zewnętrznych podwyższyło do $6,83 \%$.

Tabela 3. Zatrudnienie skazanych w Areszcie Śledczym w Inowrocławiu w 2013 r.

\begin{tabular}{|c|c|c|}
\hline Rodzaj zatrudnienia & Liczba skazanych & Struktura [\%] \\
\hline $\begin{array}{c}\text { Odpłatne prace } \\
\text { porządkowe i pomocnicze }\end{array}$ & 37 & 22,98 \\
\hline $\begin{array}{c}\text { Nieodpłatne prace } \\
\text { porządkowe i pomocnicze }\end{array}$ & 79 & 49,07 \\
\hline $\begin{array}{c}\text { Kontrahenci } \\
\text { pozawiezienni }\end{array}$ & 11 & 6,83 \\
\hline $\begin{array}{c}\text { Prace publiczne i na cele } \\
\text { charytatywne }\end{array}$ & 34 & 21,12 \\
\hline Razem & $\mathbf{1 6 1}$ & $\mathbf{1 0 0 , 0 0}$ \\
\hline
\end{tabular}

Źródło: opracowanie własne na podstawie danych uzyskanych z OISW w Bydgoszczy.

W 2013 roku, podobnie jak w latach poprzednich najliczniejszą grupę stanowili skazani zatrudnieni nieodpłatnie (70,19\%). Skazani ci przepracowali ogółem 44900 godzin. 
Dorota Kanarek-Lizik - Zatrudnienie skazanych...

\section{Zatrudnienie skazanych w Zakładzie Karnym w Inowrocławiu w latach 2014-2015}

Zakład Karny w Inowrocławiu jest jednostką penitencjarną typu półotwartego i otwartego dla skazanych mężczyzn recydywistów penitencjarnych $\mathrm{z}$ wyznaczonym oddziałem terapeutycznym dla mężczyzn uzależnionych od alkoholu. Obecna pojemność Zakładu Karnego wynosi 346 miejsc $^{2}$.

Stan zaludnienia w Zakładzie Karnym w Inowrocławiu w 2014 r. wynosił 326 skazanych (na dzień 31.12.2014 r.). Zatrudniano 225 osób, współczynnik powszechności zatrudnienia skazanych znacząco się podwyższył z 45,35\% (na koniec 2013 r.) do 69,02\% (na koniec 2014 r.). Wzrost współczynnika powszechności zatrudnienia skazanych jest związany ze zmianą przeznaczenia jednostki tj. utworzeniem zakładu karnego dla recydywistów penitencjarnych typu półotwartego i otwartego. W warunkach zakładu karnego większa ilość skazanych spełniała kryteria pozwalające na zatrudnienie, w szczególności na zewnątrz jednostki.

Tabela 4. Zatrudnienie skazanych w Zakładzie Karnym w Inowrocławiu w 2014 r.

\begin{tabular}{|c|c|c|}
\hline Rodzaj zatrudnienia & Liczba skazanych & Struktura [\%] \\
\hline $\begin{array}{c}\text { Odpłatne prace } \\
\text { porządkowe i pomocnicze }\end{array}$ & 44 & 19,56 \\
\hline $\begin{array}{c}\text { Nieodpłatne prace } \\
\text { porządkowe i pomocnicze }\end{array}$ & 110 & 48,89 \\
\hline $\begin{array}{c}\text { Kontrahenci } \\
\text { pozawięzienni }\end{array}$ & 24 & 10,67 \\
\hline $\begin{array}{c}\text { Prace publiczne i na cele } \\
\text { charytatywne }\end{array}$ & 47 & 20,89 \\
\hline Razem & $\mathbf{2 2 5}$ & $\mathbf{1 0 0 , 0 0}$ \\
\hline
\end{tabular}

Źródło: opracowanie własne na podstawie danych uzyskanych z Zakładu Karnego w Inowrocławiu.

2 Tamże. 
W tabeli 4. przedstawiono zatrudnienie skazanych w Zakładzie Karnym w Inowrocławiu w 2014 r. Poziom zatrudnienia skazanych $\mathrm{w}$ formie nieodpłatnych prac porządkowych i pomocniczych oraz prac publicznych i na cele charytatywne pozostawał na zbliżonym poziomie do roku 2013. Mniejszą grupę skazanych zatrudniano w ramach odpłatnych prac porządkowych i pomocniczych (19,56\%). Zwiększyło się zatrudnienie na rzecz kontrahentów pozawieziennych i wynosiło $10,67 \%$.

Najwięcej skazanych pracowało nieodpłatnie tj. 69,78\%, ilość przepracowanych przez nich godzin znacząco wzrosła z 44900 w 2013 r. do 93800 w roku 2014.

W 2015 roku w Zakładzie Karnym w Inowrocławiu przebywało 317 skazanych (stan na dzień 31.12.2015 r.). Zatrudniano 235 osób, współczynnik powszechności zatrudnienia skazanych podwyższył się z 69,02\% (na koniec 2014 r.) do 74,13\% (na koniec 2015 r.)

Wzrost zatrudnienia odnotowano $\mathrm{w}$ kategorii nieodpłatne prace porządkowe i pomocnicze z 48,89\% w 2014 r. do 56,17\% w 2015 r. Zatrudnienie $\mathrm{w}$ ramach odpłatnych prac porządkowych i pomocniczych oraz na rzecz kontrahentów zewnętrznych pozostawało na zbliżonym poziomie do roku poprzedniego. Istotny spadek wystąpił w zatrudnieniu skazanych przy pracach publicznych i na cele charytatywne z 20,89\% w 2014 r. do $12,34 \%$ w 2015 r.

W 2015 roku zatrudniano nieodpłatnie 68,51\% skazanych. Ilość przepracowanych przez skazanych godzin wzrosła i wynosiła 103200.

Zakład Karny w Inowrocławiu prowadzi właściwą politykę w celu zapewniania pracy jak największej licznie skazanych. Systematycznie prowadzona jest akcja informacyjna dotycząca możliwości zatrudnienia osób pozbawionych wolności na terenie Inowrocławia i okolic. W celu pozyskania nowych kontrahentów pozawieziennych przeprowadza się $\mathrm{z}$ potencjalnymi pracodawcami bezpośrednie rozmowy informujące o możliwości otrzymania ulgi w postaci ryczałtu z tytułu zatrudnienia odpłatnego skazanych. Promowana jest też idea zatrudniania skazanych jako podstawowego środka resocjalizacji. Wskazane 
Dorota Kanarek-Lizik - Zatrudnienie skazanych...

jest zwiększanie liczby odpłatnie zatrudnionych skazanych na rzecz kontrahentów zewnętrznych oraz pozyskiwanie nowych kontrahentów. Praca odpłatna jest korzystniejsza nie tylko dla skazanego, ale także dla jego rodziny.

Tabela 5. Zatrudnienie skazanych w Zakładzie Karnym w Inowrocławiu w 2015 r.

\begin{tabular}{|c|c|c|}
\hline Rodzaj zatrudnienia & Liczba skazanych & Struktura [\%] \\
\hline $\begin{array}{c}\text { Odpłatne prace } \\
\text { porządkowe i pomocnicze }\end{array}$ & 46 & 19,57 \\
\hline $\begin{array}{c}\text { Nieodpłatne prace } \\
\text { porządkowe i pomocnicze }\end{array}$ & 132 & 56,17 \\
\hline $\begin{array}{c}\text { Kontrahenci } \\
\text { pozawięzienni }\end{array}$ & 28 & 11,91 \\
\hline $\begin{array}{c}\text { Prace publiczne i na cele } \\
\text { charytatywne }\end{array}$ & 29 & 12,34 \\
\hline Razem & $\mathbf{2 3 5}$ & $\mathbf{1 0 0 , 0 0}$ \\
\hline
\end{tabular}

Źródło: opracowanie własne na podstawie danych uzyskanych z Zakładu Karnego w Inowrocławiu.

W opinii autorki, realizacja dyrektywy zawartej w art. $67 \S 3$ k.k.w na przykładzie Aresztu Śledczego/Zakładu Karnego w Inowrocławiu w latach 2011-2015 przedstawia się bardzo dobrze, szczególnie na tle innych jednostek penitencjarnych inspektoratu bydgoskiego. Zakład Karny w Inowrocławiu w analizowanym okresie jest jednym z liderów w zakresie liczby zatrudnianych skazanych.

\section{Zatrudnienie skazanych z punktu widzenia pracodawców i więźniów}

Zatrudnienie skazanych jest korzystne zarówno dla pracodawców jak i dla samych skazanych. Pracodawca zatrudniając skazanych obniża koszty pracy, może liczyć na stałą liczebność grupy roboczej i zatrudnienie fachowca. Ponadto ma możliwość uzyskania zwrotu ryczałtu w wysokości $20 \%$ wartości wynagrodzeń oraz uzyskania pożyczki 
bądź dotacji. Z kolei skazani poprzez pracę zdobywają doświadczenie i umiejętności, a także środki finansowe (przy zatrudnieniu odpłatnym) na własne potrzeby. Uczą się właściwych postaw społecznych i nawyku pracy. Wzrasta u nich poczucie samorealizacji i przynależności oraz odpowiedzialności.

Analizując zagadnienie zatrudnienia skazanych nie można pominąć obaw społecznych dotyczących ich pracy takich jak np. niskie umiejętności i kwalifikacje, znaczna fluktuacja zatrudnionych, brak odpowiednich nawyków związanych z pracą, ryzyko związane z ucieczką $\mathrm{z}$ miejsca pracy i popełnienia przestępstwa, zła sytuacja na rynku pracy, zawiłe przepisy i procedury.

Mając na uwadze korzyści z zatrudnienia skazanych oraz związane z tym obawy społeczne autorka uważa, że osadzony ma prawo do pracy tak samo jak człowiek wolny. Należy zapewnić skazanemu w miarę możliwości świadczenie pracy, ponieważ jako pozbawiony wolności nie może tej pracy sam znaleźć. Dzięki zatrudnieniu skazany może pomagać materialnie rodzinie. Sprzyja to utrzymywaniu z nią więzi. Poza tym ogromne znaczenie mają względy resocjalizacyjne.

Autorka ma nadzieję, że tendencja zatrudnienia skazanych będzie utrzymywała się i wykazywała kierunek wzrostowy. Analiza statystyczna poziomu zatrudnienia skazanych oraz przegląd poszczególnych kategorii zatrudnienia ma na celu pokazanie właściwych zmian rysujących się $\mathrm{w}$ systemie penitencjarnym $\mathrm{w}$ obszarze pracy więźniów. Wydaje się, że właściwe jest poddanie badaniom innych zakładów karnych w celu porównania jak wygląda tam to zagadnienie. Autorka chciałaby taką analizę przeprowadzić na przykładzie Zakładu Karnego we Włocławku, co będzie przedmiotem odrębnego artykułu.

\section{Podsumowanie i wnioski}

W ramach podsumowania niniejszych rozważań autorka wysunęła następujące wnioski: 
Dorota Kanarek-Lizik - Zatrudnienie skazanych...

1. W latach 2011-2015 współczynnik powszechności zatrudnienia skazanych osiągał zmienne wartości. Powszechność zatrudnienia skazanych przedstawiała się następująco: 2011 r. - 47,28\%, 2012 r. - 43,65\%, 2013 r. - 45,35\%, 2014 r. - 69,02\%, 2015 r. - 74,13\%. Pozytywnym kierunkiem jest wzrost współczynnika powszechności zatrudnienia skazanych w latach 2014-2015. Jest to związane ze zmianą przeznaczenia jednostki penitencjarnej i utworzeniem zakładu karnego a tym samym większą ilością skazanych spełniających kryteria, pozwalające na ich zatrudnienie.

2. Dominującym rodzajem zatrudnienia wśród skazanych jest zatrudnienie nieodpłatne $\mathrm{tj}$. prace porządkowe i pomocnicze oraz prace publiczne i na cele charytatywne. Powyższe formy zatrudnienia skazanych są realizowane na rzecz administracji publicznej oraz organów samorządu terytorialnego. Najwyższy odsetek skazanych zatrudniano nieodpłatnie w 2012 r. (76,16\%). Wzrost zatrudnienia nieodpłatnego w 2012 r. był związany ze znacznym obniżeniem zatrudnienia na rzecz kontrahentów zewnętrznych. W analizowanym okresie skazani średnio przepracowali nieodpłatnie 61180 godzin.

3. Poziom zatrudnienia skazanych przy pracach publicznych i na cele charytatywne osiągał zmienne wartości. Najwięcej skazanych pracowało $\mathrm{w}$ tej formie $\mathrm{w}$ latach 2013-2014, ponad 20\%, zaś najniższy odsetek skazanych odnotowano w 2015 roku, tj. $12,64 \%$.

4. W latach 2011-2015 zatrudnienie odpłatne skazanych przy pracach porządkowych i pomocniczych kształtowało się na zbliżonym poziomie tj. 2011 r. - 20,69\%, 2012 r. - 19,19\%, 2013 r. 22,98\%, 2014 r. - 19,56\%, 2015 r. - 19,57\%. Stan zatrudnienia skazanych w ramach odpłatnych prac porządkowych i pomocniczych jest zależny od ilości przyznanych ze środków budżetowych więziennictwa tzw. etatów kalkulacyjnych.

5. Najwyższy odsetek skazanych zatrudnianych na rzecz kontrahentów pozawieziennych zarejestrowano w 2011 r. tj. 12,64\%. 
Spadek zatrudnienia nastąpił w 2012 r. i został wywołany konsekwencjami wejścia w życie, z dniem 8 marca 2011 roku, zmiany przepisu w Kodeksie karnym wykonawczym, dotyczącego zasad ustalania wynagrodzenia skazanego, zatrudnionego $\mathrm{w}$ pełnym wymiarze czasu pracy oraz niechętnym podejściem do uregulowań związanych z możliwością pozyskania środków z Funduszu Aktywizacji Zawodowej Skazanych oraz Rozwoju Przywięziennych Zakładów Pracy przez potencjalnych kontrahentów. Obniżenie stanu $\mathrm{w}$ zatrudnieniu na rzecz kontrahentów zewnętrznych, wynikało ze zmiany przepisów, ale także $\mathrm{z}$ ograniczonego zapotrzebowania na pracę skazanych przez podmioty zewnętrzne. Niewątpliwie miało to związek z wysokim poziomem bezrobocia w województwie kujawsko-pomorskim $(17,9 \%$ na koniec 2012 roku), które - według danych GUS - plasowało się na jednym z pierwszych miejsc w kraju. Od 2013 r. zatrudnienie skazanych na rzecz kontrahentów pozawieziennych systematycznie rosło, by w 2015 roku osiągnąć poziom 11,91\%.

6. Wskazane jest zwiększanie poziomu zatrudnienia odpłatnego, które jest korzystniejsze dla skazanych oraz dla ich rodzin. Nowy program w tym zakresie pt. „Praca więźniów” ogłosiło Ministerstwo Sprawiedliwości w dniu 27.04.2016 r. Program „Praca więźniów" składał się będzie z trzech filarów tj. programu budowy 40 hal produkcyjnych przy zakładach karnych, rozszerzenia zakresu możliwości nieodpłatnej pracy więźniów na rzecz samorządów [ustawa] oraz ulg dla przedsiębiorców zatrudniających więźniów [ustawa]. Najbardziej interesujący jest filar pierwszy, w ramach którego zakładane jest zrealizowanie w latach 2016-2023 programu budowy 40 hal przemysłowych przy zakładach karnych, w których będą mogli pracować więźniowie. Środki będą pochodzić z Funduszu Aktywizacji Zawodowej Skazanych oraz Rozwoju Przywięziennych Zakładów Pracy. Środki na ten Fundusz pochodzą z potrąceń z wynagrodzeń więźniów, zatem program nie będzie finansowany z pieniędzy podatników. 
Dorota Kanarek-Lizik - Zatrudnienie skazanych...

\section{Bibliografia:}

Kodeks karny wykonawczy, Wydawnictwo C.H. Beck, Warszawa 2015.

Analiza stanu zatrudnienia osadzonych $w$ jednostkach penitencjarnych inspektoratu bydgoskiego w 2011 roku, OISW, Bydgoszcz 2012.

Analiza stanu zatrudnienia osadzonych $w$ jednostkach penitencjarnych inspektoratu bydgoskiego w 2012 roku, OISW, Bydgoszcz 2013.

Analiza stanu zatrudnienia osadzonych $w$ jednostkach penitencjarnych inspektoratu bydgoskiego w 2013 roku, OISW, Bydgoszcz 2014.

Informacja o stanie zatrudnienia osadzonych $w$ Zakładzie Karnym $w$ Inowrocławiu w 2014 roku, Inowrocław 2015.

Informacja o stanie zatrudnienia osadzonych $w$ Zakładzie Karnym w Inowrocławiu w 2015 roku, Inowrocław 2016.

Kanarek-Lizik D., Stankowski W., Dzieje Zakładu Karnego w Inowrocławiu. $Z$ dziejów polskich jednostek penitencjarnych, Tom II, POZKAL, Inowrocław 2014.

Ustawa z dnia 28 sierpnia 1997 r. o zatrudnieniu osób pozbawionych wolności, Dz. U. 1997 Nr 123 poz. 777. 